\title{
Indonesian Personal Data Protection Concept: A Book Review "Kebebasan Informasi Versus Hak atas Privasi: Tanggung Jawab Negara dalam Perlindungan Data Pribadi"
}

\author{
Rizqi Mulyani Slamet \\ Faculty of Law, Universitas Negeri Semarang \\ Email: rizqi.mulyanislamet06@gmail.com
}

\section{Citation:}

Slamet, R. M. (2021). Indonesian Personal Data Protection Concept: A Book Review "Kebebasan Informasi Versus Hak atas Privasi: Tanggung Jawab Negara dalam Perlindungan Data Pribadi". Lex Scientia Law Review, 5(1), 179-184, doi: https://doi. org/10.1 5294/lesrev.v5i1.46904

\section{History of Article}

Received: May 22, 2021

Revised: May 17, 2021

Accepted: May 25, 2021

(C) The Author(s)

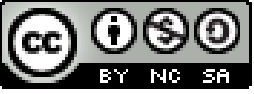

This work is licensed under a Creative Commons Attribution-NonCommercial-ShareAlike 4.0 International License.

All writings published in this journal are personal views of the authors and do not represent the views of this journal and the author's affiliated institutions.

Lex Scientia Law Review published by Faculty of Law, Universitas Negeri Semarang, Indonesia in collaboration of UKM Lex Scientia. Published biannuallyevery May and November.

\section{BOOK DATA}

Book title

: Kebebasan Informasi

Versus Hak atas Privasi :

Tanggung Jawab Negara

dalam Perlindungan

Data Pribadi

$\begin{array}{lll}\text { Author } & : & \text { Dr. Nenny } \\ & & \text { Rianarizkiwati, SH, } \\ & \text { LL.M. } \\ \text { Publisher } & : & \text { Infermia Publishing } \\ \text { Publication Year } & : & 2020 \\ \text { Publisher City } & : & \text { Depok } \\ \text { Book Language } & : & \text { Indonesia } \\ \text { Number of pages } & : & 372 \text { pages } \\ \text { Book ISBN } & : & 978-623-7799-11-5\end{array}$

\section{KEYWORDS}

Protection of Personal Data; Right to Information; Right to Privacy 


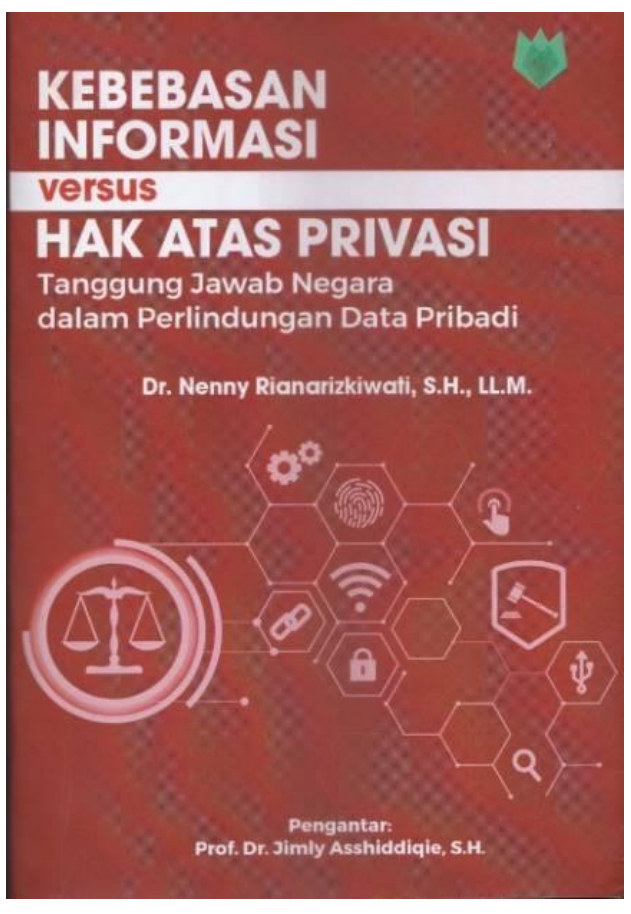

This book is written based on Dr. Nenny Rianarizkiwati, SH, LL.M. The book entitled Freedom of Information versus the Right to Privacy contains how the state can protect everyone's personal data. In a democratic state life, there will be two conflicting interests: the need for information disclosure and the need for protection of the confidentiality of information or the right to information and the right to privacy. Universal Declaration of Human Rights and International Covenant on Civil and Political Rights are two legal instruments that recognize these rights in human rights and include rights that may be limited to fulfillment by the state. Limitation of the right to information means respecting the privacy rights of others so that the right to information and privacy has clear boundaries. So that it can protect individuals from collecting information that can violate privacy. The presence of the state in personal data protection arrangements can make it easier for everyone to understand their rights and obligations regarding access to confidential information or data. In Indonesia, the history and development of personal data protection have not shown a clear concept regarding the direction of the policy. Indonesia needs to establish regulations to reinforce the state's role as the person responsible for implementing personal data protection. It is in line with the 1945 Constitution, which emphasizes that the state's responsibility is to protect, advance, uphold, and fulfill human rights. It is clear how the responsibility for the right to protection of personal data needs to be established and implemented in the relationship between government and citizens as well as in the relationship between individuals. The government has the responsibility to determine the direction of personal data protection policies considering Indonesian local wisdom.

Furthermore, there is an agreement between the ASEAN Telecommunication and Information Ministers in the ASEAN subregion as support for the creation of a digital economy environment made in November 2016 and outlined in the Framework on Personal Data Protection, which contains seven principles in it. The substance of the constitution on the right to privacy of information in the regions of each continent regulates the types of activities guaranteed. Through the history of the debate on the recognition of human rights in the 1945 constitution between communalistic and individualistic ideas, it has resulted in an agreement to include human rights 
and the rights of citizens in the constitution. This agreement was successfully embodied in the body of the 1945 Constitution which was ratified at the PPKI session on August 18, 1945. The 1945 Constitution does not have a special chapter regulating human rights but it can be traced to particular articles and paragraphs.Then, In 2000, There is a second amendment to the 1945 Constitution regarding the regulation of Human Rights in Chapter XA with as contained in articles 28A to 28J with as many as 26 regulations.The 1945 Constitution also regulates restrictions on the exercise of rights to recognize and respect the rights and freedoms of others.

Furthermore, the freedom of information contained in Article $28 \mathrm{~F}$ of the 1945 Constitution is translated in more detail through The Act Number 14 of 2008 concerning Freedom of Information. This law guarantees a balance between access to information and the right to privacy; that is, on the one hand, everyone can exercise their right to access information. On the other hand, everyone is obliged to comply with regulations regarding confidential information so it cannot be accessed. Article 28G paragraph (1) results from changes in ideas and concepts in line with the right to privacy. Indonesia is taking a middle ground in translating the right to privacy as the right to personal protection.

The case regarding the use of personal data from bank customers and the dissemination of information via email is an example that the Indonesian public has started to understand the importance of protecting personal data. The decision regarding the use of bank customers' personal data began when a customer sued three corporations, namely two banking companies (BCA and Citibank) and the pay-television company Indovision because they were deemed to have used their personal data incompatible with the purpose for which they were collected. The plaintiff acknowledges that BCA has mutually cooperated with Citibank and Indovision regarding the interconnection of an online network based on card-based payment instruments through BCA Automated Teller Machines (ATM). Then there is an exchange of personal data between the three corporations for smooth online customers. On the other hand, the plaintiff never permitted the defendants to use and disseminate their personal data among the defendants. The plaintiff considers the actions of the defendants to be illegal, without rights and against the law and not under the provisions of Article 1 number 28, Article 40, Article 43, and Article 45 of The Act Number 7 of 1992 concerning Banking as amended by The Act Number 10 of 1998. The Plaintiffs questioned the imposition of collection fees, levies, and additional fees in the form of payment fees through BCA ATMs made by Citibank if the plaintiff paid bills through BCA ATMs. 
This charge shows that BCA has reciprocal cooperation with Citibank so that the plaintiff considers it an act of disclosing, leaking, and revealing the secrets of the plaintiff's bank.

The panel of judges examining this lawsuit rejected all of the plaintiff's claims because the plaintiff could not prove that the payment via BCA ATM meant that the plaintiff's personal data had been leaked under the control of BCA, Citibank or Indovision; the plaintiff has knowingly made bill payments using BCA ATMs without coercion by anyone so that they should understand that the plaintiff shared information related to card numbers or customer numbers; Payment via BCA ATM does not mean Citibank and Indovision are aware of all of the plaintiff's banking transactions recorded at BCA. Furthermore, cases related to defamation through email. A citizen expressed his disappointment with the health services he received at one of the hospitals. This disappointment was expressed through private emails that were distributed to colleagues not to be disseminated to the public. However, the Panel of Judges at the cassation level decided that the defendant was guilty of deliberately and without the right to distribute and / or transmit and / or make accessible electronic information and / or electronic documents that had the contents of defamation and / or defamation. This case illustrates the circulation of personal data to other parties that are not suitable for purpose. Email should be written by someone and only addressed to certain people who are listed as recipients of the message. It should not be disseminated to other unauthorized persons without the author's permission as the data owner.

Personal data protection arrangements are studied through 2 (two) approaches. There are the subjective approach adopted by the United States and the objective approach adopted by the European Union, each of which has its weaknesses and strengths. Indonesia has 3 (three) options to apply which approach is most appropriate to the conditions and needs of the nation to protect personal data. There aresubjective approach, objective approach and hybrid approach (a combination of subjective objectives). The United States point of view sees privacy as an aspect of freedom or liberty. Privacy as freedom means that privacy accepts differences, considering that there is space in social norms that can be ignored and sees someone as having the authority to determine something based on their own thoughts. In America, the state exists as a facilitator for the community to regulate or determine the privacy of information. The United States citizens believe that the state does not need to interfere with privacy protection mechanisms through state administration. If the data owner is not disturbed, the dissemination of the data is not considered a violation of the right to information privacy. If it does 
not permit the information collector to forward his personal data for other than the agreed purpose, the owner has an opt-out option.

Meanwhile, Europe views privacy as dignity (honor). Privacy as an award means that someone puts forward cooperation, respects the application of social norms, and feels bound to one another as a colonial society that interacts with the same norms. The state can intervene in data protection mechanisms through an official body authorized to carry out investigations. Everyone has the same perception that every data someone owns remains the property of that person and does not belong to the one controlling or processing the data. If the owner does not declare an opt-in, it will automatically be deemed not to have permitted to use data or information other than what has been agreed upon.

The hybrid regulatory model ensures that the state acts as a regulator that determines the rules and principles for implementing information privacy and allows the state to form and determine personal data protection regulations while providing opportunities for other competent parties to implement mechanisms and find solutions to protect personal data. Regulations related to personal data protection that have been published in Indonesia that reflect the application of hybrids are Government Regulation Number 82 of 2012 concerning the Implementation of Electronic Systems and Transactions. The Personal Data Protection Bill itself reduces the principles of personal data protection to eight principles. First, personal data collection is limited and specific, legally valid, appropriate, and transparent. Second, the processing of personal data is carried out for its purpose. Third, the processing of personal data is carried out by guaranteeing the rights of the owner of the personal data. Fourth, the processing of personal data is carried out accurately, completely, not misleadingly, up to date and can be accounted for. Fifth, the processing of personal data is carried out by protecting the security of personal data from unauthorized access, unauthorized disclosure, unauthorized alteration, misuse, destruction and / or loss of personal data. Sixth, the processing of personal data is carried out by notifying the purpose and activity of processing and failure of protecting personal data. Seventh, personal data is destroyed and / or deleted after the retention period ends or at the request of the owner of the personal data unless otherwise stipulated by laws and regulations.

Thus, this book discusses comprehensively regarding the protection of personal data, in which it is revealed that Indonesia does not yet have a clear concept regarding the protection of personal data with information disclosure, even reflecting on the cases described in this book it is seen that regulations 
have not adequately protected the right to privacy. So that the issues in this book are pretty clear that the Indonesian government has not fully agreed on the right to privacy as part of protected human rights. The right to information and the right to privacy are rights that contradict each other's implementation. The right to information prioritizes individual freedom to seek all the information desired, while the right to privacy limits the space for individuals to seek specific information related to a person's personal data. The Law on Freedom of Public Information frees everyone to pursue all public information with restrictions on a person's private secrets. The freedom to obtain information and the right to privacy should be limited and implemented in a balanced manner to ensure the security and convenience of interaction between the government and citizens and fellow citizens. The Indonesian government needs to consider reviewing human rights arrangements, especially regarding the substance of the right to information and the right to personal protection, to clear the scope of these two rights. Article 28 G paragraph (1) in the word "protection" needs to be adjusted to become "protection," which means acts of protection. This amendment demonstrates the acceptance of the right to privacy in the constitution by integrating the contents of the articles currently in effect.

In the book Freedom of Information Versus the Right to Privacy: State Responsibilities in Protecting Personal Data, there are advantages and disadvantages. The weakness of this book is the thickness of the book, which is 372 pages, makes the material in this book too wordy and does not focus on the core material of the book. Apart from that, the presentation of cases as an urgency for the formation of personal data protection regulations is not sufficient, presumably, it is necessary to add other factual events to add references for readers so that the book does not appear merely theoretical. The advantages of this book are that it provides a lot of knowledge about personal data, its regulation and protection, and even provides a comparison of personal data protection in the countries of Asia, Europe, and America. Other than that there are many endnotes at the end of each chapter that make it easier for readers to find references in this book. In general, this book is very good for reading material related to the protection of personal data. 